VOX PATRUM 22 (2002) t. $42-43$

Sylwia STAŚKIEWICZ

(Warszawa, UKSW)

\title{
KSIĄDZ PROFESOR EMIL STANULA JAKO BADACZ ANTYKU CHRZESCIJAŃSKIEGO*
}

Jak sam Ksiądz Profesor pisze w niepublikowanym sprawozdaniu dla MEN-u, jego kierunki badań naukowych wyznaczały trzy główne czynniki: osobiste zainteresowania, wydawanie przezeń patrystycznej serii thumaczeniowej „Pisma Starochrześcijańskich Pisarzy” oraz dydaktyka. Osobiste zainteresowania ujawniły się już w pracach dyplomowych, począwszy od studiów filologicznych na UJ w Krakowie i studiów teologicznych na ATK w Warszawie, poprzez doktorat i habilitację, gdzie na czoło wysunęła się antropologia filozoficzna, teologiczna eklezjologia oraz egzegeza patrystyczna, a fascynacja tą dziedziną wiedzy przetrwała aż do śmierci. Ulubionymi jego autorami okazali się Tertulian i Hilary z Poitiers, którego wszystkie pisma przełożył na język polski ${ }^{1}$.

W sumie owocem zainteresowań ojca profesora Emila Stanuli jest aż 214 publikacji, w tym 3 książki, 27 artykułów, 6 przekładów pism Tertuliana, 6 przekładów pism Hilarego z Poitiers (przygotował do druku), 15 recenzji i sprawozdań, 97 haseł słownikowych lub encyklopedycznych oraz 65 opracowań redakcyjnych łącznie $\mathrm{z}$ wstępami i indeksami ${ }^{2}$.

Badania związane z przekładami dzieł literatury patrystycznej publikowanymi w serii „Pisma Starochrześcijańskich Pisarzy”, dotyczące konieczności umiejscowienia wydawanego pisma w kontekście historycznym, a także chęć ich uprzystępnienia współczesnemu czytelnikowi oraz zwrócenia uwagi na aktualność zawartej tam treści, zmuszała księdza Redaktora do podejmowania dodatkowych studiów, badań, analiz, a także lektury polskiej i obcojęzycznej literatury. Wynikiem tych studiów i badań jest opracowanie około $70 \%$ wstępów do poszczególnych tomów serii. W odniesieniu do pism Orygenesa i św.

* Wyciąg z pracy magisterskiej, napisanej na Wydziale Nauk Historycznych i Społecznych UKSW pod kierunkiem ks. dra hab. T. Kołosowskiego.

${ }^{1}$ Obecnie przygotowuje się ich wydanie w PSP.

${ }^{2}$ Por. A. Stępniewska, Ksiądz Profesor Emil Stanula, VoxP 17 (1997) t. 32-33, s. 11. Szczególowy ich wykaz zob. S. Longosz, Wykaz drukowanych prac Ks. Prof. Emila Stanuli, tamże, s. $15-26$. 
Augustyna wprowadzenia te, razem wzięte, mogą być traktowane jako monografie. Informacje biograficzne zostały w nich połączone $z$ elementami historyczno-kulturowymi, na których tle umieścił ks. Stanula doktrynę antropologiczną, eklezjologiczną i egzegetyczną ${ }^{3}$.

1. Badania i publikacje do czasu obrony rozprawy doktorskiej. W roku 1968 ojciec Emil Stanula ukończył studia patrystyczne, uzyskując dyplom magistra teologii w zakresie patrologii na podstawie pracy: Elementy montanistyczne $w$ eklezjologii Tertuliana przed jego formalnym przejściem na montanizm. Praca ta została oceniona na stopień bardzo dobry i została uznana za godną opublikowania w „Studia Theologica Varsaviensia”"

Autor stara się w niej odpowiedzieć na pytanie, czy i jak elementy koncepcji Kościoła, wyrażanej przez Tertuliana w pismach po formalnym przejściu na montanizm, znajdują się już, przynajmniej w postaci zalążkowej, w jego spuściźnie piśmienniczej $z$ okresu przedmontanistycznego. Motywem podjęcia takiego tematu była okoliczność, że w ostatnich czasach historycy coraz częściej i silniej podkreślają, iż przejście Tertuliana do sekty montanistów nie było nagłym przeskokiem, lecz tylko zakończeniem duchowej ewolucji, jaka się w nim dokonywała od pierwszej chwili po przyjęciu chrześcijaństwa ${ }^{5}$. Praca ta stanowi cenne studium wskazujące we wcześniejszej twórczości Tertuliana elementy, które w pełni dochodzą do głosu dopiero po przejściu Tertuliana na montanizm $^{6}$, a zarazem dowodzi, że ks. Emil Stanula już w pierwszym okresie swojej pracy naukowo-badawczej ujawnił się jako dobry badacz antyku chrześcijańskiego: potrafil postawić ciekawe problemy badawcze oraz wykazał umiejętność właściwej i wnikliwej analizy tekstu patrystycznego, a następnie jego interpretacji. Wystarczy podać jeden przykład: Ksiądz Stanula, stawiając Tertulianowi pytanie o jego koncepcję Kościoła w okresie przedmontanistycznym, cytuje najpierw jego zdanie $\mathrm{z}$ traktatu De oratione:

„W Ojcu wzywa się i Syna, bo jest powiedziane: «Ja i Ojciec jedno jesteśmy» (J 10, 30). Nie pomija się tu i Matki - Kościoła. Wszak w Synu i Ojcu wyznaje się i matkę; w niej znajduje się imię ojca $i$ syna. Tak więc $w$ tym samym sposobie wyrażania i slowie oddajemy cześć Bogu, pamiętamy o przykazaniu i wspominamy tych, którzy zapomnieli o Ojcu"7.

${ }^{3}$ Por. A. Stępniewska, Ksiądz Profesor Emil Stanula, art. cyt., s. 11.

${ }^{4}$ Por. E. Stanula, Elementy montanistyczne w eklezjologii Tertuliana przed jego formalnym przejściem na montanizm, STV 9 (1971) z.1, 105-145.

5 Por. Akta studenckie księdza E. Stanuli, nr 1092, Archiwum UKSW - recenzja ks. prof. M. Michalskiego na temat pracy dyplomowej ks. E. Stanuli.

${ }^{6}$ Por. Akta studenckie księdza E. Stanuli, nr 1092, Archiwum UKSW - recenzja ks. doc. dra H. Bogackiego na temat pracy dyplomowej ks. E. Stanuli.

${ }^{7}$ De oratione 2, CCL 1, 258, thum. W. Kania, PSP 5, 115-116. 
Tertulian w tej wypowiedzi nazywa Kościół Matką, a tak rozumiany Kościół odnosi do Osób Boskich: Ojca i Syna. Ks. Stanula w swojej analizie tego tekstu wydobywa te relacje w sposób następujący:

„W tej wypowiedzi Tertulian najpierw wskazuje na relacje, jakie zachodzą między Ojcem, Synem i Kościolem. Ojciec pozostaje z jednej strony w relacji do Syna, jako Ojciec, ale z drugiej strony i do Matki - Kościoła, z którą ma Syna. Bo gdy wymawiamy Ojciec, myślimy i o Synu i o Matce"8.

Tekst ten jednak nasuwa ks. Stanuli problem badawczy, który stawia on następująco:

"Czy Tertulian pojmuje tę «Matkę» na sposób boski jak Ojca i Syna, jako identyczną z ożywiającym ją Duchem Świętym? Trudno dać jednoznaczną odpowiedź. Wewnętrzny stosunek Ojca do Syna oraz uderzające pominięcie osoby Ducha Świętego w tym fragmencie, skłania raczej do odpowiedzi pozytywnej. Wzywa się Ojca - mówi Tertulian - ale nie ma ojca bez dzieci, tak jak nie mogą znów istnieć dzieci bez ojca i bez matki. W ten sposób Ojciec, Syn i Matka tworzą stosunek pokrewieństwa, w którym jedna osoba warunkuje drugą; Kościół «Matka» przedstawiony jest jako Duch Święty, przez którego ustawicznie rodzi Ojcu nowe dzieci i nowych synów"9.

Ks. Stanula potrafił tutaj postawić trudne pytanie, na które niełatwo jest dać jednoznaczną odpowiedź. Odważnie jednak tej odpowiedzi udziela, a następnie w jej świetle dokonuje jeszcze bardziej pogłębionej interpretacji trudnego przecież tekstu Tertuliana. To tylko jcdno zobrazowanie pracy badawczej ks. Stanuli nad myślą Ojców Kościoła prezentowaną w ich dziełach, i to już z pierwszego okresu jego twórczości naukowej. Znajomość kolejnych jego publikacji pozwala stwierdzić, że takie podejście do badań cechuje całe jego żcie naukowe.

Owocem studium ks. Emila Stanuli nad dziełami Tertuliana zarówno z katolickiego, jak i montanistycznego okresu twórczości Kartagińczyka, jest nie tylko wyżej omówiona praca magisterska, ale także dokonanie przez niego przekładu na język polski kilku dzieł tego autora. W 1970 r. w piątym tomie „Pism Starochrześcijańskich Pisarzy” ukazało się aż pięć pism Tertuliana w jego thumaczeniu: Do męczenników, Preskrypcja przeciw heretykom, O chrzcie, O cierpliwości, $O$ pokucie. Przekłady te zostały opatrzone stosownymi komentarzami.

W tym okresie, po zainicjowaniu serii wydawniczej PSP, ks. Stanula wziął na siebie większość trudu związanego $\mathrm{z}$ pracą redakcyjną przy pierwszych sześciu jej tomach: Święty Cyprian, Listy; Święty Grzegorz Wielki, Dialogi; Święty Grzegorz Wielki, Homilie na Ewangelie; Swięty Ambroży, Hexaeme-

${ }^{8}$ Elementy montanistyczne $w$ eklezjologii Tertuliana przed formalnym przejściem na montanizm, dz. cyt., s. 117.

${ }^{9}$ Tamże. 
ron; Kwintus Septymiusz Florens Tertulian, Wybór Pism; Święty Hieronim, $O$ znakomitych męzach. Pielgrzymka do miejsc świętych ${ }^{10}$. W tomach tych sporządził indeksy: cytatów biblijnych, nazw własnych i rzeczowy, a także opracowal te tomy pod względem merytorycznym.

Wszystkie wyżej wymienione artykuły, przekłady, indeksy, opracowania merytoryczne i redakcyjne stanowią ważną część dorobku ojca Stanuli, który czy to jako autor, czy to jako thumacz starał się udostępniać już przełożone pisma starochrześcijańskie tak, aby każdy mógł z nich swobodnie korzystać.

Prace te ks. Stanula łączył z badaniami nad dziełami Ambrozjastra. Owocem tych badań było uzyskanie w 1972 r. stopnia naukowego doktora teologii w zakresie patrologii na podstawie rozprawy: Nauka Ambrozjastra o stanie pierwotnym człowieka ${ }^{11}$. Praca ta została opublikowana $\mathrm{w}$ jednym $\mathrm{z}$ pierwszych tomów serii "Studia Antiquitatis Christianae"12.

Do podjęcia przynajmniej częściowego opracowania poglądów Ambrozjastra w zakresie antropologii teologicznej skłoniło ks. Stanulę posiadanie pełnego krytycznego wydania dzieł tego autora. Ojcu Stanuli chodziło o odpowiedź na podstawowe dla całej tej dziedziny pytanie: jak wyobrażał sobie Ambrozjaster pierwotny stan czlowieka, to jest przed pierwszym upadkiem. Zagadnienie to, stanowiące samo dla siebie pewną całość, a zarazem punkt wyjścia nauki o grzechu pierworodnym i łasce, było dla ks. Stanuli tym bardziej interesujące i inspirujące, że nie zostało do tamtej pory monograficznie opracowane.

W omawianej rozprawie ks. Stanula usiłuje przynajmniej w ogólnych liniach odpowiedzieć na pytanie, dokąd prowadzi teologiczna antropologia Ambrozjastra oraz komu jest on w swych poglądach bliższy: Augustynowi czy Pelagiuszowi; główny jednak nacisk położył na dokładną rekonstrukcję poglądów Ambrozjastra na temat pierwotnego stanu człowieka. Ponieważ jedną $\mathrm{z}$ cech charakterystycznych poglądów Ambrozjastra jest bardzo ścisłe wiązanie stworzenia świata materialnego i człowieka $z$ upadkiem pewnej liczby duchów niebieskich, tj. aniołów, dlatego ks. Stanula uznał za konieczną analizę doktryny Ambrozjastra o stanie pierwszych ludzi przed grzechem rajskim poprzedzić ogólnym przedstawieniem jego poglądów na sferę istot czysto duchowych oraz na środowisko materialne, w jakim Bóg umieścił czlowieka i wyznaczył mu w nim specjalną rolę do spełnienia. Kolejnym pytaniem zadanym w drugiej części rozprawy jest: czy Ambrozjaster pojmowal pierwotny stan czlowieka jako czysto naturalny, czy też przypisał mu pewne dary Boskie, które utracil przez grzech pierworodny?

${ }^{10}$ Por. S. Longosz, Wykaz drukowanych prac Ks. Prof. Emila Stanuli, art. cyt., s. 15-17.

11 Por. niepublikowane sprawozdanie ks. E. Stanuli z działalnosci naukowo-badawczej specjalności historii literatury wczesnochrześcijańskiej ATK dla Ministerstwa Edukacji Narodowej, s. 9 (maszynopis).

12 Por. E. Stanula, Nauka Ambrozjastra o stanie pierwotnym cztowieka. Studium z zakresu antropologii teologicznej, SACh 1, z. 2, Warszawa 1977, ss. 120. 
Opublikowana drukiem rozprawa doktorska księdza Emila Stanuli ukazuje go jako badacza, który jeszcze bardziej rozwija ujawnione już wcześniej talenty naukowo-badawcze. Analizując pisma autorów wczesnochrześcijańskich potrafił stawiać problemowe pytania i na podstawie gruntownej analizy i interpretacji ich dzieł - dokonać jasnego, syntetycznego ujęcia ich myśli w różnych egzegetycznych i teologicznych kwestiach.

2. Badania i publikacje między doktoratem a habilitacją. Okres między doktoratem a habilitacją obejmował 10 lat (1972-1982). W tym czasie ks. Stanula jako badacz antyku dokonał wiele. Po pierwsze, opublikował 6 artykułów naukowych w polskich periodykach, teologicznych i patrystycznych, jak "Studia Theologica Varsaviensia”, „Collectanea Theologica”, „Tarnowskie Studia Teologiczne”, „W Drodze”, „Vox Patrum”. Jeden z tych artykułów: Aniołowie oraz ich upadek wedtug Ambrozjastra, jest jeszcze rezultatem badań prowadzonych w związku z rozprawą doktorską. Pozostałe zaś artykuty dowodzą, że w tym okresie ks. Emil Stanula skierował swoją uwagę badawczą na dzieła teologiczne i egzegetyczne św. Hilarego z Poitiers, dotychczas w badaniach i publikacjach polskich badaczy antyku chrześcijańskiego niemal nieobecnego ${ }^{13}$. W artykułach tych przedstawił duchową sylwetkę biskupa Poitiers, a także jego myśl na temat modlitwy chrześcijańskiej. Wskazują na to tytuły opublikowanych wówczas artykułów: Droga św. Hilarego z Poitiers do Boga ${ }^{14}, S$ w. Hilarego o Trójcy świętej (I 1-2 ${ }^{15}$, Modlitwa w wykładzie teologicznym św. Hilarego $z$ Poitiers ${ }^{16}$, Uwagi na temat znaczenia stowa medytacja $w$ komentarzach biblijnych św. Hilarego $z$ Poitiers ${ }^{17}$.

Zainteresowania badawcze ks. Stanuli dzielami Hilarego z Poitiers skloniły go także wówczas do rozpoczęcia przekładu na język polski dzieł tego autora. Zamiarem jego było przetłumaczenie wszystkich dzieł biskupa Poitiers i wydanie ich jednocześnie w serii „Pisma Starochrześcijańskich Pisarzy”18.

$\mathrm{Z}$ wydawaniem po 1972 roku kolejnych tomów tej serii wiążą się także kolejne tematy badawcze Księdza Profesora w tym okresie. Nadal brał on na

${ }^{13} \mathrm{~W}$ tamtym okresie na temat św. Hilarego z Poitiers ukazała się w Polsce tylko jedna o poważniejszym naukowym charakterze publikacja, i to w języku łacińskim, por. L . Małunowiczówna, De voce sacramenti apud S. Hilarium Pictaviensem, Lublin 1956.

${ }^{14}$ "W Drodze" 5 (1977) nr 3, 95-103.

15 "W Drodze" 5 (1977) nr 5, 97-105.

16 "Tarnowskie Studia Teologiczne” 8 (1981) 175-178.

17 Tamże, s. 233-238.

${ }^{18}$ Zamiar ten nie zostal dotychczas zrealizowany. Po śmierci Księdza Profesora dotarto do maszynopisów tych przekładów i obecny zespół redakcyjny PSP pracuje nad ich wydaniem. Niedawno (2002 r.) w przekładzie ks. Stanuli ukazały się dwa dziełka egzegetyczne św. Hilarego: Komentarz do Ewangelii św. Mateusza oraz Traktat o tajemnicach (PSP 63). W opracowaniu redakcyjnym znajdują się przekłady kolejnych dzieł. 
siebie najwięcej prac związanych $\mathrm{z}$ opracowaniem merytorycznym i redakcyjnym tych tomów oraz opracowaniem indeksów. Poza tym wydania kolejnych tomów PSP skłaniały go do bardziej szczegółowych badań naukowych nad dziełami tych Ojców Kościoła, których dzieła w serii „Pisma Starochrześcijańskich Pisarzy" udostępniano polskim czytelnikom. Stąd ks. Stanula prowadził w tym okresie bardziej szczegółowe badania nad dziełami egzegetycznymi i apologetycznymi Orygenesa, działalnością literacką św. Augustyna i literaturą monastyczną. Wskażmy tylko na ważniejsze artykuły naukowe Księdza Profesora, które stanowiły wstępy do różnych tomów PSP: Apologia Orygene$s a^{19}$, Teologiczne zasady interpretacji Pisma świętego ${ }^{20}$, Ojciec chrześcijańskiej interpretacji Pisma świętego ${ }^{21}$, Literacka dziatalność św. Augustyna ${ }^{22}, \dot{Z} y c i e$ codzienne w klasztorze św. Doroteusza z Gazy $y^{23}$.

Ksiądz Profesor Emil Stanula był także w tych i następnych latach autorem wielu haseł encyklopedycznych dotyczących pisarzy wczesnochrześcijańskich i spraw dotyczących historii Kościoła w starożytności. W sumie napisał okolo 125 hasel do Encyklopedii katolickiej KUL, Stownika Pisarzy Antycznych, do stownika: Abecedariusz. Pisarze wczesnochrześcijańscy I-VII wieku oraz Encyklopedii kultury bizantyjskiej.

O dojrzałości naukowo-badawczej świadczą także recenzje publikacji patrystycznych, zwłaszcza książek stanowiących o światowej literaturze patrologicznej. Ksiądz Emil Stanula w okresie między doktoratem a habilitacją napisal 10 recenzji różnych książek z zakresu patrologii, dotyczących wczesnochrześcijańskiej literatury greckiej i łacińskiej, jakie ukazały się w językach: angielskim, niemieckim i francuskim. Recenzje te opublikowal w czasopismach wydawanych przez Akademię Teologii Katolickiej: "Collectanea Theologica” i „Studia Philosophiae Christianae".

Zapoczątkowane w tym okresie jego działalności badawczo-twórczej zainteresowania piśmiennictwem oraz myślą teologiczną i egzegetyczną św. Hilarego $\mathrm{z}$ Poitiers zaowocowały rozprawą habilitacyjną. Ksiądz Profesor Emil Stanula habilitował się w 1982 r. na podstawie dorobku naukowego i rozprawy: Czynniki ksztattujące sens biblijny w ujęciu św. Hilarego z Poitiers ${ }^{24}$. Roz-

\footnotetext{
${ }^{19}$ Por. Orygenes, Przeciw Celsusowi, thum. S. Kalinkowski, PSP 17, Warszawa 1977, 26-43.

20 Por. Orygenes, O zasadach, thum. S. Kalinkowski, PSP 23, Warszawa 1979, $34-56$.

${ }^{21}$ Por. Orygenes, Komentarz do Ewangelii św. Jana, thum. S. Kalinkowski, PSP 28, Warszawa 1981, 20-48.

${ }^{22}$ Por. Sw. Augustyn, O nauce chrześcijańskiej, tłum. J. Sulowski, PSP 22, Warszawa 1979, 153-179.

${ }^{23}$ Por. Św. Doroteusz z Gazy, Nauki ascetyczne, tłum. M. Borkowska, PSP 27, Warszawa 1980, 12-28.

24 Por. niepublikowane sprawozdanie ks. E. Stanuli z działalności naukowo-badawczej specjalności historii literatury wczesnochrześcijańskiej ATK dia Ministerstwa Edukacji Narodowej, s. 9 (maszynopis).
} 
prawa ta została opublikowana w „Studia Antiquitatis Christianae” w 1984 r., jako jej czwarty tom ${ }^{25}$.

Problem badawczy, jaki w tej rozprawie stawia ks. Emil Stanula pod adresem pism Biskupa z Poitiers, dotyczy w ogóle problemu interpretacji danych filozoficznych, religijnych, a zwłaszcza tekstów starożytnych. Nie jest on nowy, skoro już Arnobiusz w polemice $\mathrm{z}$ interpretatorami mitów greckich i łacińskich stawiał pytanie, dlaczego jedne należy rozumieć alegorycznie, a inne dosłownie. Ten sam problem pojawił się w chrześcijańskiej egzegezie Pisma świętego. Współczesnemu czytelnikowi nasuwa się pytanie: dlaczego egzegeta patrystyczny zamiast interpretować tekst, wykładał swoje myśli przy lekturze tekstu świętego? Dlaczego Pismo św. przybierało formę tylko dekoracyjną, względnie podpierającą autorytet teologa życia wewnętrznego? W jakim celu patrystyczny egzegeta przypisuje tekstom biblijnym własny sens, często za pośrednictwem tak sztucznych środków, jak np. wymyślne etymologie, symbolika arytmetyczna, wykładnia imion osób, nazw miejscowości lub poszukiwanie intencji autora w zbędnych szczegółach lub brak jakiegoś elementu, czy wreszcie trudnościach dosłownego rozumienia tekstu?

Alegoryczną interpretacją posługiwano się od samego początku istnienia Kościoła, ponieważ w ten sposób interpretowane Pismo św. stanowiło podstawę jedności Kościoła, a Ojcowie Kościoła nie widzieli przeciwstawności między alegorycznym a dosłownym rozumieniem Pisma świętego.

Narzuca się więc pytanie o podstawy alegorycznej interpretacji Ojców Kościoła oraz o sposób łączenia literalnej i alegorycznej interpretacji Pisma św., wreszcie o kryterium tożsamości teologii. Czy egzegeci patrystyczni są świadomi tego, że uprawiając alegoryczną interpretację, w miejsce sensu Boga wstawiają własne poglądy teologiczne i religijne? Czym wytłumaczyć fakt, że uprawiając przypadkową, samowolną, subiektywną egzegezę stworzyli taką teologię, dzięki której pomimo różnic osobowościowych i kulturowych wytyczyli ramy dalszego jej rozwoju, a dla siebie stworzyli grunt, na którym stojąc odrzucali poglądy nieortodoksyjne?

Takie oto problemy naukowo-badawcze związane z egzegezą patrystyczną stawiał ks. Emil Stanula, gdy przystępował do realizacji swojej rozprawy habilitacyjnej. Były to kwestie bardzo ważne, których rozwiązanie bez wątpienia ulatwiało zrozumienie egzegezy Ojców Kościoła. Ks. Stanula stawia tutaj problemy, które pomagają odkryć rację, podstawy, uzasadnienia i logikę takiej egzegezy i takich poglądów teologicznych, jakie Ojcowie Kościoła pozostawili w swoich pismach.

Ks. Stanula zdawał sobie sprawę, że próbę odpowiedzi na tak postawione problemy badawcze można by było podjąć opierając się bądź na całej literatu-

${ }^{25}$ Por. E. Stanula, Czynniki ksztattujqce sens biblijny w ujęciu św. Hilarego z Poitiers, SACh 4, Warszawa 1984. 
rze patrystycznej, bądź na wybranych, ale w pewnym sensie modelowych pismach jednego $\mathrm{z}$ pisarzy starożytności chrześcijańskiej. W swojej rozprawie habilitacyjnej obrał tę drugą ewentualność z wielu względów. Patrolodzy, którzy poszukiwali źródeł myśli teologicznych Ambrozjastra,, zwrócili uwagę ks. Stanuli nie tylko na znaczenie dla historii interpretacji tekstu świętego malo znanych pism egzegetycznych św. Hilarego, lecz nadto pokazali pewną „modelowość" tego ostatniego dla przedaugustyńskiej egzegezy. Ożywione zaś studia ostatnich dziesiątków lat wykazały, że św. Hilary skupia w swych pismach zróżnicowaną tradycję egzegetyczną i teologiczną całego Kościoła. Studiując pisma egzegetyczne Biskupa z Poitiers ojciec Stanula dostrzegł, że jego stałą troską było podanie racji, dla których on uważa, że odkryty sens jest sensem biblijnym, co więcej - sensem zaaprobowanym przez Kościół.

Należy jednak z góry zaznaczyć, że w rozprawie nie chodzi o sens biblijny rozpatrywany sam w sobie, w jego istocie, elementach konstytutywnych, rodzajach, metodach odkrywania, lecz o sens biblijny w ujęciu Hilarego w konkretnym zastosowaniu. Stanula starał się odkryć w procesie dochodzenia do tego sensu tę podstawę, a raczej te czynniki lub te elementy, czy te konkretne dane, które zaprowadziły św. Hilarego do takiego sensu, jaki zamknąl i przekazał w swych pismach egzegetycznych.

Przedmiotem zatem pracy ojca Stanuli jest ta praca egzegetyczna św. Hilarego, która znajduje się pomiędzy punktem wyjścia, to jest tekstem świętym, a punktem odejścia, to jest tekstem odczytanym i sformułowanym w pismach egzegetycznych. Śledząc zaś ten odcinek procesu egzegetycznego Ksiądz Stanula zmierzal do wykrycia tych faktów, czy tych motywów, czy powodów, które sugerowały, wskazywały, albo $w$ końcu zadecydowały o takim rozumieniu Pisma św., jaki znajduje się w wymienionych pismach egzegetycznych (Komentarz do Ewangelii św. Mateusza, "Traktaty do Psalmów, Traktat o Tajemnicach). Ponieważ jednak wiele spraw interesujących ojca Stanulę znajdowało szersze i wyraźniejsze omówienie w traktacie św. Hilarego O Trójcy Świętej, niejednokrotnie się uciekał do wypowiedzi z tego traktatu, który nie jest pismem egzegetycznym. Zasadniczą jednak podstawą źródłową były pisma egzegetyczne św. Hilarego.

Rozprawa składa się z czterech rozdziałów. Wypowiedzi z pism egzegetycznych św. Hilarego mówią o tekście Pisma św., o jego specyfice, o rzeczywistości, o której mówi tekst biblijny, wreszcie o zadaniach egzegety. Treść tych wypowiedzi ks. Stanula ujął w tytuły poszczególnych rozdziałów. Kierunek badań ojca Stanuli jest następujący: wychodząc od wykrycia tych elementów tekstu biblijnego, które Biskup z Poitiers uważa za istotne dla sensu, następnie analizując treści, a więc „ducha” Pisma Świętego, ks. Stanula starał się odkryć w hilariańskich pismach te wewnętrzne racje, które niejako zmusiły Biskupa z Poitiers do odejścia od litery Pisma Świętego i podyktowały mu taki sens, jaki zawarl w swych pismach egzegetycznych. 
3. Badania i publikacje po habilitacji. Po uzyskaniu stopnia naukowego doktora habilitowanego teologii w zakresie patrologii ks. Emil Stanula kontynuuje z pasją badania nad spuścizną literacką Ojców Kościoła. Od tego czasu aż do swojej śmierci, opublikowal 28 artykułów naukowych w książkach wieloautorskich oraz czasopismach teologicznych i patrystycznych ("Vox Patrum", "Studia Theologica Varsaviensia”, „Śląskie Studia Historyczno-Teologiczne”, „Saeculum Christianum”), z czego 12, to wstępy do kolejnych tomów PSP. Jak przedstawia się w świetle tych publikacji tematyka badawcza Księdza Profesora w tym okresie jego działalności naukowej?

Ksiądz Stanula po habilitacji nie zaprzestał badań nad tekstami św. Hilarego z Poitiers. Niektóre $\mathrm{z}$ nich, jak rozprawa habilitacyjna, dotyczą działalności egzegetycznej Biskupa z Poitiers ${ }^{26}$. Księdza Profesora zajmowały w tym okresie także inne aspekty pisarskiej działalności i nauczania św. Hilarego, jak jego działalność kościelno-polityczna ${ }^{27}$, sakramentologia ${ }^{28}$ i pneumatologia ${ }^{29}$. W publikacjach tych $\mathrm{z}$ właściwą już sobie wnikliwością analizuje i interpretuje dziela św. Hilarego pod kątem postawionych problemów badawczych, próbując dać syntezę jego myśli na poszczególne tematy. Zwraca przy tym uwagę na ewolucję myśli św. Hilarego w poszczególnych kwestiach czy też na specyfikę jego nauczania na dany temat w poszczególnych okresach twórczości, nie zapominając o uwarunkowaniach historyczno-kościelnych, w jakich określone dzieło powstawało ${ }^{30}$.

Twórczość św. Hilarego z Poitiers zajmuje więc szczególne miejsce w badaniach i publikacjach księdza profesora Emila Stanuli. Ten fakt czyni go nie tylko wybitnym patrologiem, ale wręcz hilarologiem, zajmującym poczesne miejsce wśród światowych badaczy myśli Biskupa z Poitiers.

${ }^{26}$ Por. Wartość Septuaginty w rozumieniu św. Hilarego z Poitiers, VoxP 4 (1984) z. 6-7, 304 316; Chrystocentryzm duchowej interpretacji Pisma świętego w ujęciu św. Hilarego z Poitiers, STV 23 (1985) z. 2, 217.237.

${ }^{27}$ Por. „Non possumus” św. Hilarego z Poitiers, „Śląskie Studia Historyczno-Teologiczne” 18 (1985) 181-189; „Imperatoria sollicitudo” w ocenie św. Hilarego z Poitiers, w: Chrześcijanie a życie publiczne w Cesarstwie Rzymskim III-IV wieku, red. J. Srutwa, Lublin 1988, 105-122.

28 Por. Stót Stowa Bożego wedtug "Traktatu do 13 psalmu” św. Hilarego z Poitiers, VoxP 7 (1987) z. 12-13, 355-370; Sw. Hilary z Poitiers o Eucharystii, w: Pokarm nieśmiertelności. Eucharystia w życiu pierwszych chrześcijan, red. W. Myszor - E. Stanula, Katowice 1987, 157-176; Hilariańska symbolika matzeństwa i rodziny w "Komentarzu do Ewangelii św. Mateusza", w: Kościót - rodzina - wychowanie. Ksiega Jubileuszowa prof. Janiny Stominskiej, Warszawa 1998, 203-218; Uwagi św. Hilarego z Poitiers na temat Apostotów, biskupów i kaptanów, w: Kościót socjologia - statystyka. Księga Jubileuszowa prof. Witolda Zdaniewicza, Warszawa 1999, 218-227.

${ }^{29}$ Por. Dar Ducha świętego w ujęciu św. Hilarego z Poitiers, w: Droga doskonalenia chrześcijańskiego w epoce patrystycznej. Zagadnienia wybrane, red. F. Drączkowski - J. Pałucki - M. Szram, Lublin 1997, 137-150.

${ }^{30}$ Por. Dar Ducha Świętego, art. cyt., s. 137-150; Sw. Hilary z Poitiers o Eucharystii, art. cyt., s. 157.176 . 
Badania nad św. Hilarym nie wyczerpują jednak zainteresowań naukowych Księdza Profesora w tym okresie. Z łacińskich Ojców Kościoła przedmiotem badawczej uwagi byli: Hieronim i Rufin z Akwilei ${ }^{31}$, Augustyn ${ }^{32}$, Chromacjusz z Akwilei ${ }^{33}$ i św. Cezary z Arles ${ }^{34}$, a z Ojców greckich Orygenes ${ }^{35}$ i Jan Chryzostom $^{36}$. Wiele $\mathrm{z}$ tych artykulów to wstępy poprzedzające teksty wybranych dzieł Ojców Kościoła w serii „Pisma Starochrześcijańskich Pisarzy”. Warto zwrócić uwagę na przynajmniej niektóre tytuły: Wychowanie chrześcijańskie $i$ jego problemy; Orygenes - nauczyciel życia duchowego; Twórcza rola tlumaczy; Pismo święte z problemami w rozumieniu św. Augustyna; Święty Augustyn wyznaje, jak pokonat opór względem Pisma świętego. Już samym sformułowaniem tytułów Ksiądz Profesor stara się zwrócić uwagę czytelnika i zainteresować go dziełem Ojca Kościoła, które zostało przetłumaczone w danym tomie „Pism”. Z jednej strony chodzi tutaj o wzbudzenie zainteresowania, a z drugiej o właściwe wprowadzenie czytelnika w lekturę dzieła, które powstało w odległych czasach, w innym okresie historyczno-kulturowym.

Odwołajmy się przykładowo do opracowania: Święty Augustyn wyznaje, jak pokonat opór względem Pisma świętego ${ }^{37}$. Jest to wstęp do jednego

${ }^{31}$ Por. Twórcza rola tłumaczy, w: Hieronim, Apologia przeciw Rufinowi, tłum. S. Ryznar, PSP 51, Warszava 1989, 5-20.

32 Por. ., 'Wyznania” św. Augustyna o przyjaźni, VoxP 8 (1988) z. 15, 881-890; Chrystus Ewangelistów czy historyczny w ujęciu św. Augustyna, w: Augustyn, $O$ zgodności Ewangelistów, tlum. J. Sulowski, PSP 50, Warszawa 1989, 5-16; Pismo święte z problemami $w$ rozumieniu św. Augustyna, w: Augustyn, Problemy Heptateuchu I, thum. J. Sulowski, PSP 46, Warszawa 1990, 5-12; Święty Augustyn wyznaje, jak pokonat opór względem Pisma świętego, w: Augustyn, Problemy Heptateuchu II, thum. J. Sulowski, PSP 48, Warszawa 1990, 5-18.

${ }^{33}$ Por. Chromacjusz z Akwilei - cztowiek i jego dzieto, w: Chromacjusz z Akwilei, Kazania $i$ homilie, tłum. S. Ryznar, PSP 49, Warszawa 1991, 5-14.

${ }^{34}$ Por. Chrześcijanie, do których przemawiat św. Cezary z Arles, w: Cezary z Arles, Kazania $i$ homilie, thum. S. Ryznar, PSP 52, Warszawa 1989, 5-15.

35 Por. Wychowanie chrześcijańskie i jego problemy, w: Orygenes, Komentarz do Ewangelii wedtug św. Mateusza, tłum. S. Kalinkowski, ZMT 10, Kraków 1998, 5-32; Homiletyczna działalność Orygenesa, w: Orygenes, Homilie o Księdze Jeremiasza, Homilie o Księgach Samuela i Księgach Królewskich, tlum. S. Kalinkowski, PSP 30, Warszawa 1983, 5-20; Orygenes, nauczyciel zycia duchowego, w: Orygenes, Homilie o Ksieggach Rodzaju, Wyjścia, Kapłaniskiej, thum. S. Kalinkowski, PSP 31, Warszawa 1984, 7-20; Zycie duchowe w ujęciu Orygenesa, w: Orygenes, Homilie o Księgach Liczb, Jozuego, Sędziów, tłum. S. Kalinkowski, PSP 34, Warszawa 1986, 9-30; W drodze ku czlowiekowi wewnętrznemu, w: Orygenes, Komentarz do Listu św. Pawła do Rzymian, tłum. S. Kalinkowski, PSP 57, Warszawa 1994, 11-38; Człowiek wewnętrzny wedhug Orygenesa, w: Orygenes, Komentarz do Listu św. Pawta do Rzymian, tłum. S. Kalinkowski, PSP 57, Warszawa 1994, 11-42.

${ }^{36}$ Por. Rodzina ksztattujqca system wartości w ujęciu św. Jana Chryzostoma, w: Wychowanie $w$ rodzinie od starożytności po wiek XX. Materiaty $z$ konferencji naukowej Katedry Historii Wy. chowania (czerwiec 1993 r.), red. J. Jundzill, Bydgoszcz 1993, 81-94.

${ }^{37}$ Por. Sw. Augustyn, Problemy Heptateuchu II, thum. J. Sulowski, PSP 48, Warszawa 1990, 5-18. 
z egzegetycznych dzieł św. Augustyna: Problemy Heptateuchu, w którym wyjaśnia on różne kwestie dotyczące pierwszych siedmiu ksiąg Pisma św. Starego Testamentu. Ksiądz Profesor przedstawia we wstępie, że sam Augustyn, autor tego dzieła egzegetycznego, miał od młodości wiele problemów ze zrozumieniem Pisma św., a w pewnym okresie niewłaściwe zrozumienie ksiąg natchnionych zaprowadziło go na błędną drogę wiary. Czytelnikowi sięgającemu po dzieło patrystyczne komentujące Pismo św. ks. Stanula w pierwszym zdaniu wstępu przypomina:

„Pismo święte nie było i nie jest łatwą lekturą. Dla wielu budzi ono opór nie tylko $\mathrm{z}$ racji treści, ale nawet samej formy zewnętrznej; ale po przezwyciężeniu jednych i drugich trudności pozostaje opór wynikający z konsekwencji życiowych tej lektury" ${ }^{38}$.

Problemy z Pismem św. mają wierni zawsze, aż po czasy dzisiejsze. Opory budzą jeśli już nie jego forma zewnętrzna i treść, to przynajmniej właśnie konsekwencje życiowe, jakie wynikają z treści. Wszystkie te problemy przeżył „na swojej skórze” Augustyn, który teraz chce wyjaśnić wiernym, często zawiłe, starotestamentalne kwestie. Ksiądz Stanula w omawianym wstępie na podstawie analizy Wyznań św. Augustyna stara się ukazać całą „przygodę” tego autora $z$ Pismem świętym, to, w jaki sposób sam Augustyn stopniowo dojrzewał do lektury Pisma świętego, przezwyciężając powyższe trzy opory. Ten wstęp to nie tylko dokonany na podstawie analizy odpowiednich fragmentów Wyznań Biskupa Hippony opis i periodyzacja jego drogi do Boga, a w związku $\mathrm{z}$ tym i do lepszego zrozumienia i umiłowania Pisma św., ale także doskonała zachęta i dobre wprowadzenie w samą lekturę dzieła egzegetycznego Augustyna. Taką wartość nosi w sobie wiele innych publikacji Księdza Profesora $\mathrm{z}$ tego okresu.

\section{PROFESSOR AEMILIUS STANULA ASSIDUUS SCRUTATOR ANTIQUITATIS CHRISTIANAE}

\section{(Argumentum)}

Hac in dissertatiuncula, quae tribus partibus constat, gesta atque studia Aemilii Stanula CSsR (1935-1999), professoris Varsoviensis Academiae Theologiae Catholicae necnon auctoris amplissimae Polonorum collectionis patristicae „Pisma Starochrześcijańskich Pisarzy” (Scripta Scriptorum Paleochristianorum) chronologice praesentantur.

\footnotetext{
${ }^{38}$ Swięty Augustyn wyznaje, jak pokonat opór względem Pisma świętego, art. cyt., s. 5.
} 